\title{
An alternative conceptualization of indigenous rights in Africa under the international human rights law framework
}

\author{
Una conceptualización alternativa de los derechos indígenas \\ en África en el marco del derecho internacional \\ de los derechos humanos
}

Ruwadzano P. Makumbe ${ }^{1}$

ruwamakumbe@gmail.com

Summary: Introduction. 1. Ethno-cultural diversity and indigenous rights. 2. A historical narrative of the development of the Indigenous peoples' rights movement in post-colonial Africa. 2.1. A scholarly reflection on the International indigenous rights movement and its relationship with indigeneity in Africa. 3. Indigenous Rights and Human Rights. 4. Case Study: The Tshwa San Peoples in Zimbabwe. 4.1 Zimbabwe's Approach to Indigeneity. 4.2 San Peoples in Zimbabwe. 4.3 Reversing the implementation gap: Ethno-cultural diversity as a tool for indigenous rights protection in Zimbabwe. Conclusions. Bibliography.

\begin{abstract}
This article is a practice-based elucidation of how indigenous rights can be securely protected and implemented in the broader human rights discourse. The concept of indigeneity is contested in many African countries with the primary question being: Who is indigenous? The 'politics of recognition' have stalled the work of the African indigenous rights movement thus far and this paper builds upon the discourse on Indigenous rights, making a proposition towards an effective machinery to facilitate their protection. Therefore, the focus is to construct a different perspective which emphasizes the need to utilize, develop and improve the existent human rights machinery. This is done through the reconceptualization of indigenous rights by utilizing

1 Ruwadzano is a qualified Zimbabwean lawyer. She holds a Bachelor of Laws honors degree from the University of Zimbabwe and the Joint Erasmus Mundus Master's degree in Human Rights Policy and Practice from Deusto University (Bilbao, Spain), Gothenburg University (Gothenburg, Sweden) and Roehampton University (London, Uk).
\end{abstract}


the ethno-cultural protections machinery. In the last part of this article I look at the San peoples in Zimbabwe as a representative case study to bring into perspective the lived realities of indigenous peoples in Africa.

Keywords: human rights, ethno-cultural diversity/protections, indigenous rights, Africa.

Resumen: Este artículo es una aclaración basada en la práctica de cómo los derechos de los indígenas, según lo establecido en el derecho internacional de los derechos humanos, pueden protegerse e implementarse de manera segura en el discurso más amplio de los derechos humanos. El concepto de indigenismo se impugna en muchos países africanos y la pregunta principal es: ¿quién es indígena? Las "políticas de reconocimiento" han paralizado el trabajo del movimiento de derechos indígenas africanos hasta el momento y este documento se basa en el discurso sobre los derechos indígenas, haciendo una propuesta hacia una maquinaria efectiva para facilitar su protección. Por lo tanto, el enfoque es construir una perspectiva diferente que enfatice la necesidad de utilizar, desarrollar y mejorar la maquinaria existente de derechos humanos. Esto se hace a través de la reconceptualización de los derechos indígenas en África a través de la utilización de la maquinaria de protección etno-cultural. En la última parte de este artículo, veo a los pueblos San en Zimbabwe como un estudio de caso representativo para poner en perspectiva las realidades vividas de los pueblos indígenas en África.

Palabras clave: derechos humanos, diversidad etno-cultural/protecciones, derechos indígenas, África. 


\section{Introduction}

The Universal Declaration of Human Rights (1948) provides the foundation for human rights recognition and protection. The Preamble of the Declaration sets a tone on the universality of human rights and their applicability to every human being regardless of their political, cultural or religious backgrounds. Over the years the international human rights regime has developed, expanding the scope of human rights mechanisms under international law (Freeman 2011, 157). This development has also been seen in the area of indigenous rights protection. Though in beginning the indigenous rights discourse was somewhat overshadowed by the discourse on minority rights, through the various efforts of activists, indigenous peoples, scholars and organizations the indigenous rights discourse has emerged as an independent body of knowledge under the international human rights framework. In light of this, it is however crucial to note that despite the often intersection between indigenous rights and minority rights, not all minority groups are indigenous and not all indigenous groups are minorities. As such, the normativity of the indigenous rights discourse is instituted in the need to protect the cultural identity of indigenous communities and ensure that the human rights of these groups are promoted.

It is also imperative to note that despite there being human rights documents specifically protecting indigenous rights, 'mainstream' international human rights mechanisms also provide, implicitly and explicitly for the protection of indigenous rights. Common Article 1 to the International Covenant on Civil and Political Rights (ICCPR) and International Covenant on Economic Social and Cultural Rights (ICESCR) are quintessential examples. The basis of indigenous rights is the recognition that ethno-cultural diversity and special categories of rights have been developed and established allowing for specialized human rights protection. From this brief analogy, the main argument of this paper is that ethno-cultural diversity is a category under the broader scope of human rights protection mechanisms. As an emerging narrative it therefore instigates the debate on empowerment and protection of indigenous groups and I emphasizes the importance of finding the balance under contemporary human rights discourses (Malloy 2006). As such, the relationship between these two concepts of human rights and ethno-cultural diversity are the main subjects of analysis, with the aim of elucidating how ethno-cultural diversity can be utilized as a tool to conceptualize progressive understanding of 'indigenousness' in African States, where indigenousness as a debatable concept is resisted and not recognized. 


\section{Ethno-cultural diversity and Indigenous Rights}

In the human rights discourse it has been the motif that the concept of ethno-cultural diversity is closely linked to the narrative on the protection of minorities. In the European context, there is a myriad of instruments dedicated to the protection of minorities, most of which are at the State level and based on citizenship and the impending need to create equality between the majority and the minority (Malloy $2006,8-9)$. This can be traced back to the treaty of Westphalia (1648) which ushered a new dispensation that was premised on sovereignty. It is of essence to note that the Peace of Westphalia ended the thirty years war of 1618-1648 between the Catholic allies and the Protestant powers and subsequently resulted in the collapse of Catholic Church rule and the formation of the Sovereign State (Webb 2012, 77; Dersso $2010,43-44)$. As such, cultural identities have always shaped the social structure of states particularly the political functions. In international human rights law the first instance where cultural diversity was recognized was through Article 27 of the ICCPR which provides that:

In those States in which ethnic, religious or linguistic minorities exist, persons belonging to such minorities shall not be denied the right, in community with the other members of their group, to enjoy their own culture, to profess and practice their own religion, or to use their own language.

In this provision multiculturalism is acknowledged on the premise of individual rights, particularly emphasizing the right to freedom of religion or culture. This position has been further argued for by Joseph Raz's interest-based conception of rights (1988). He argues that individual and collective rights are premised on and shaped by individual rights. In this regard, the role of ethno-cultural diversity is therefore both direct and indirect. In the last few decades, people have become more aware of their identities such that claims of minority rights have become prominent (Yacoub 2010: 11). Recent examples are the Catalan in Spain, the Scottish in the United Kingdom and the Kurd in the Middle East. Multiculturalism and diversity are concepts that cannot be ignored as globalization has prompted migration, creating and reshuffling communities (Venkatasawmy 2015, 31).

The structuralizing of societies into dominant groups and minority groups is a dissociation not fundamentally based on numbers but also on cultural and political dominance as well as superiority in the political economy and market. This realization culminated in the development 
of two separate discourse on minority rights and on indigenous rights. This was influenced by the need to address the specific challenges faced by these groups particularly assimilation (Dersso 2010, 7). Realizing this, in 1989 the International Labour Organization (ILO) adopted the Indigenous and Tribal Peoples Convention (ILO Convention No. 169)2. It replaced ILO Convention 107 which had an assimilationist approach and did not therefore adequately provide for the protection of indigenous rights ${ }^{3}$. Convention 169 provides a basis for the protection of indigenous peoples, though not setting out a clear definition, it highlights the characteristics that distinguish indigenous peoples in different parts of the world (International Labour Organisation 2009). In 1992 the General Assembly adopted Resolution 47/135, Declaration on the Rights of Persons Belonging to National or Ethnic, Religious and Linguistic Minorities. This Declaration reaffirmed Article 27 of the ICCPR and went further to include national minorities. It emphasized the rights that Article 27 provided for making it an obligation of States to protect minorities' interests at the national level. Though it was an independent mechanism from the indigenous rights focused efforts it affirmed the struggles of both minority and indigenous groups.

In the past three decades, the protection of indigenous has taken center-stage with rights activists making arguments on selfdetermination and self-protection (Nabudere 2005). The right to self-determination is provided for in Article 1 common to the ICCPR and ICESCR and scholars such as Kuper and Kenrick have argued for the need for indigenous groups to claim this right as a basis of their existence. Of interest is the Reference case which was before the Supreme Court of Canada. In that case, the court made a distinction between internal self-determination and external self-determination. With this distinction in mind, the court held that "external self-

2 Indigenous and Tribal Peoples Convention, 1989 (No. 169). Convention concerning Indigenous and Tribal Peoples in Independent Countries (Entry into force: 05 September 1991). Adoption: Geneva, 76th ILC Session (27 June 1989)-Status: Upto-date instrument (Technical Convention). Available online at, http://www.ilo.org/dyn/ normlex/en/f?p=NORMLEXPUB:12100:0::NO::P12100_ILO_CODE:C169 Accessed on 14 May 2018.

3 Indigenous and Tribal Populations Convention, 1957 (No. 107). Convention concerning the Protection and Integration of Indigenous and Other Tribal and SemiTribal Populations in independent Countries (Entry into force: 02 June 1959). Adoption: Geneva, 40th ILC Sessions (26th June 1957). Status: Outdated instrument (Technical Convention). Available online at, http://www.ilo.org/dyn/normlex/en/f?p=NORMLEXPUB: 12100:0::NO::P12100_ILO_CODE:C107 Accessed on 14 May 2018. 
determination in the form of 'remedial secession' would be contingent upon the state failing to respect 'internal' self-determination" (Supreme Court of Canada 1998). This basically entails that the right to self-determination is not motivated by political secession but by selfprotection and self-governance by indigenous communities. Under the minority rights discourse it has been argued that, one effect of the dominance of the discourse on ethno-cultural diversity is that it has fueled inter-ethnic or cultural conflicts (Venkatasawmy 2015, 30-31). This has been the case in Africa and examples are the 1994 Rwandan Genocide which was an inter-ethnic conflict between the Hutu and Tutsi ethnic groups (United to End Genocide). Also, violent riots and killings in DRC, Burundi and Uganda were inter-ethnic conflicts (Venkatasawmy 2015, 31).

However, international law has continued to ensure the protection of indigenous populations and the Vienna Declaration and Programme of Action (World Conference on Human Rights 1993) plays an important role in this regard. The Declaration reaffirms respect for human rights without distinction of race, culture, sex or language. It goes further to recognize and acknowledge the changes that are taking place on the international scene and that States should respect the diversity and culture of indigenous peoples (World Conference on Human Rights 1993, preamble). Despite the fact that the Vienna Declaration was not particularly focused on indigenous rights, it speaks about the 'universal nature of human rights' and provides for the protection for indigenous rights in the mainstream and also distinctively. Further protection of indigenous rights is seen in the UNESCO Universal Declaration on Cultural Diversity (2001). The Declaration takes a more pragmatic approach and looks at culture as a broad concept which encompasses lifestyle, value system and traditions. It recognizes that cultural diversity has resulted in the intermixing and clashing of cultures and provides for tolerance and dialogue as prerequisites for peace and security. It further acknowledges that globalization together with new information and communication technologies present new challenges for cultural diversity but at the same time an opportunity for dialogue among cultures (Nabudere 2005). Following this Declaration, the UNESCO General Conference adopted the UNESCO Convention on the Protection and Promotion of the Diversity of Cultural Expressions (2005). The Declaration reinforces the protection of human rights as provided in previous human rights documents and also stresses on the obligation of States to respect cultural diversity and protect both indigenous populations and minorities at both international and national levels (UNESCO General Conference 2005). 
The indigenous rights discourse thus fits in the human rights discourse. It allows for indigenous groups to claim their rights independent of the minority narrative. Borrowing from realism and the regime theory, indigenous rights have subsisted in a culture where despite the marginalization of concerns for human rights by states, states have continued to be part of the international regime which consists of rules and institutions to which they commit themselves such as the United Nations Declaration on the Rights of Indigenous Peoples (Freeman 2011, 157). This regime has facilitated human rights actions which have facilitated the efforts made to give prominence to the indigenous rights discourse. Emphasis ought to be put on the essence of the UNDRIP as it puts indigenous peoples in a distinct category allowing them to claim protection and protection of their rights from that perspective. As human rights are broad and dynamic, they create space for mechanization that allows for the promotions and protection of such rights. This is reflected in the ethno-cultural diversity narrative. As a socio-political category, ethno-cultural diversity is a flexible tool which was initially utilized in the minorities discourse. In this paper, I argue that its flexibility allows it to be an efficient tool to facilitate the protection and promotion of indigenous rights as an independent discourse from the minority discourse. The above analysis on how ethno-cultural diversity has developed as an integral part of human rights clearly shows that diversity, multiculturalism and pluralism in its flexible form has shaped societies and continues to do so (Venkatasawmy 2015). As a significant category of the human rights narrative, ethno-cultural diversity is therefore significant in facilitating the protection of indigenous rights.

\section{A historical narrative of the development of the Indigenous peoples' rights movement in post-colonial Africa}

The indigenous rights movement in Africa can be traced back to Moringe Parkipuny, a leader of an NGO representing Maasai peoples from Tanzania. In a historic and first ever act, Parkipuny presented a statement to the United Nations Working Group on Indigenous Peoples (UNWGIP) in 1989 (Bojosi 2010, 98). He asserted that "in postcolonial Africa the state monopoly of national identities opened the door for prejudices against and violations of the rights of "peoples with cultures that are different from those of the mainstream of national population" (Hodgson 2009, 1-2). He indicated that there were two main categories of vulnerable minority peoples whose rights were 
being violated; hunter gatherers and pastoralists. This was important in the development of the indigenous rights movement in Africa because it illustrated that the African indigenous peoples' community was "part of the transnational community of indigenous people (Hodgson 2009 , 2). It also set in motion the creation of African networks of indigenous peoples which facilitated their participation in both regional and international platforms advocating for the recognition and protection of their rights (Hodgson 2009, 2). This was a build up to the work of José Martinez Cobo who was the Special Rapporteur of the Commission on Human Rights on the situation of human rights and fundamental freedoms of indigenous peoples. In 1983, Cobo had noted that he had "always considered that certain population groups in several African countries and regions should be considered as indigenous in those regions" (Cobo 1985). Though not in parallel terms, this observation paved a pathway for developments on the regional level.

The International Working Group on Indigenous Affairs (IWGIA) played a role in Parkipuny's participation and in 1990 it argued for the applicability of the concept of indigeneity in Africa (Bojosi, 2010). In 1993 IWGIA co-sponsored a Conference on Indigenous Peoples in Africa in Dune, Denmark. The aim was to open debate on "whether we are justified in applying the concept of indigenous peoples in Africa" (Dersso 2010, 100). The Conference "acknowledged that the concept was an external mission and sought to inquire into the propriety of doing so as there was not some broad based conscious self-ascription by certain peoples as indigenous peoples" (Dersso 2010, 100). IWGIA continued to fund and organize workshops and trainings for indigenous peoples in Africa. They also facilitated the participation of indigenous peoples at UN platforms to present their challenges and advocate for the recognition and protection of their rights by their own governments (Hodgson 2009, 6).

In 1999, IWGIA and Pastoralist Indigenous Non-Governmental Organizations Forum (PINGO) convened the Arusha Conference in Tanzania, leading the conference to request the African Commission on Human and Peoples Rights to address the challenges that were being faced by indigenous peoples (Bojosi 2010, 96-97). In particular, the Conference resolved to petition the "African Commission to include an agenda item on the rights of indigenous peoples in Africa in all its sessions and to establish a working group to consider all aspects of the rights of indigenous peoples and to prompt consideration by African states" (Hodgson 2009, 17; Bojosi 2010, 97). In its 28 ${ }^{\text {th }}$ Ordinary session, held in Cotonou in October 2000, the African commission 
adopted its Resolution 51 on the Rights of Indigenous Peoples' Communities in Africa ${ }^{4}$. Commissioner Pityana who was in attendance tabled the issue and it was adopted as an independent agenda at the $28^{\text {th }}$ session (2000) (Kipuri 2005, 1). The Resolution established the African Commission's Working Group of Experts on Indigenous Populations/Communities (African Working Group). The establishment of the Working Group has allowed for human rights issues which the African Commission would not have dealt with due to lack of machinery. Further the role of NGOs in indigenous rights protection mechanisms has been enhanced and the work of the African Working Group is facilitated by funds from NGOs (Bojosi 2010, 105).

Of significance is that Resolution 51 mandated the Working Group to "examine the concept of indigenous peoples and communities in Africa and study the implications of the African Charter on human rights and well-being of indigenous communities especially with regard to: the right to equality (Articles 2 and 3); the right to dignity (Article 5); protection against domination (Article 19); on self-determination (Article 20); and the promotion of cultural development and identity (Article 22)" (African Commission on Human and Peoples Rights, 2000). The African Working Group's report (with the support of the IWGIP) which was adopted by the African Commission on Human and Peoples Rights in 2005 is regarded by the African Commission as its "official conceptualization of, and framework for the issue of the human rights of indigenous populations and as such it is a highly important instrument for the advancement of indigenous populations' human rights situation" (African Commission's Working Group of Experts on Indigenous Populations/Communities, 9).

The Working Group has continued to support indigenous communities and the indigenous movement in Africa which has developed over the years with the support of local and international NGOs. The movement has done remarkably in its efforts to lobby with States to recognize and protect indigenous rights. One such instance is its involvement in the United Nations Declaration on the Rights of Indigenous Peoples (UNDRIP) negotiations (Hays \& Biesele 2011). They have also put a lot of pressure on African states to ratify the Declaration and as a result African States such as Tanzania, Namibia, Botswana and Kenya have put in place mechanisms to protect the rights and interests of indigenous rights particularly with

4 ACHPR/Resolution 51 (XXVIII) 00: Resolution on the Rights of Indigenous Peoples' Communities in Africa. Adopted at the 28th Ordinary Session held in October 2000 in Cotonou, Benin. 
regards to land and natural resources (Bojosi 2010). Despite these positive strides there is still resistance from States to officially recognize indigenous communities. The main arguments raised by governments are precisely centered on the right to self-determination and how its conceptualization may lead to state disintegration and territorial disputes. Another argument is that the concept of indigeneity is rather foreign and does not exactly apply in the African context as all black Africans are indigenous to Africa and making a distinction would result in the accordance of 'special rights' resulting in discrimination as was the case during colonialism (Viljoen 2010).

\subsection{A scholarly reflection on the International indigenous rights movement and its relationship with indigeneity in Africa}

Anthropologists have underpinned the importance of preserving indigenousness and this has been considered paramount in the promotion and protection of collective rights (Kuper 2003). In 2007 the United Nations Declaration on the Rights of Indigenous Peoples (UNDRIP) came into effective as an international framework setting the minimum standards with regards to the protection of indigenous peoples' rights 5 . It also cemented the indigenous rights discourse as an independent discourse and dispelled the position that it was a mere issue of minorities. The pool of literature on the impact that the global indigenous movement has had on indigenous populations is varied, with some scholars arguing that the global indigenous movement has only worsened the situations of indigenous peoples by exposing them to the harshness of social and political realities (Kuper 2003; Suzman 2003; Pelican 2003). On the other hand, some scholars have argued that the global indigenous movement has been a success and has fostered many victories that indigenous peoples globally have benefited from thus far (Robins 2003; Kenrick \& Lewis 2004). However, the question which remains is whether the international indigenous movement has facilitated significant changes in the recognition and promotion of indigenous rights in Africa.

To address this question, the departure point is Viljoen's observation on how the global indigenous movement developed. The

5 United Nations Declaration on the Rights of Indigenous Peoples (UNDRIP) A/ RES/61/295. Adopted at the 61st session of the General Assembly on Thursday 13 September 2007. Available online at, http://www.un.org/esa/socdev/unpfii/documents/ DRIPS_en.pdf Last accessed on 14 May 2018. 
movement was premised on the need for protection of indigenous populations who were identified as such based on the narrative of being 'first peoples' and having features of primitivism in their way of life (Viljoen 2010, 75). This narrative was primary, particularly in the Americas and Australasia where the contextual history was so-telling. This disposition however fell outside the African contextualization of the term indigenous, based on the historical facts. Viljoen notes that this distortion in the portrayal of what or who could be identified as indigenous has set the primary reason for the resistance by most African States to recognize and protect indigenous populations (Viljoen 2010). Anthropology scholar, Kuper $(2003,401)$ also puts across a similar point. He argues that the global indigenous movement was based on essentialist ideologies, which did not reflect the lived realities of indigenous peoples. The basis of Kuper's argument is that the indigenous movement has developed into a global paradigm fundamentally among anthropologists and has a common approach to indigenous peoples' rights (Kuper 2003). He argues that the approach is premised on American essentialist ideologies of culture and identity, as key in the discourse on indigeneity, igniting aspects such as nativity and primitivism as the determining factors (Kuper 2003).

This is an interesting factor which has arguably influenced academic research on indigenous populations. In this regard, Battiste notes that such Eurocentric approaches diminishes the concepts of diversity and multiculturalism defeating the purpose of a universal human rights (Battiste 2002, 35). The analysis by Kuper and Viljoen makes it apparent that this conceptualization of indigenous peoples' rights is not feasible in Africa and, as such, it creates complexity in the idea of protecting groups that are internationally recognized as indigenous and locally are not. As highlighted by Viljoen the global indigenous movement therefore falls short from the start as the African Union Assembly in its 2007 decision affirmed that the "vast majority of the peoples of Africa' are indigenous to the African continent" (Viljoen 2010, 76). In this regard, a quintessential example is the Constitution of Zimbabwe. Where it mentions the term indigenous it is effectively referring to black Zimbabweans (Parliament of Zimbabwe 2017, Section 33 and 295). Similarly, the Constitution of Cameroon mentions indigenous peoples and minorities specifically in its preamble, although it is not clear if the term refers to groups that are "indigenous" in the sense developed through international discourse (Sylvain 2017, 16). From the foregoing, there is a confirmation of the arguments above that the global indigenous peoples' movement is somewhat separated from the actualities of the struggles of indigenous populations in Africa. 
This illustrates the complexity of the concept of indigeneity in Africa coupled with the politics of recognition. The indigenous movement in Africa has been fighting for the recognition and protection of indigenous rights for over two decades now. The fact that there is continuous resistance by governments to officially recognize and protect indigenous rights in African countries such as Zimbabwe, Uganda, and Burundi etc. is testimony that there is a need to explore other avenues under the human rights regime to ensure that indigenous rights are protected regardless. In some African States such as the Central African Republic, Namibia, Botswana and South Africa efforts have been made to re-conceptualize the term indigenous to be relevant in the African context and there has been significant progress. In the Namibian case, an example is the Village Schools Project which was developed and implemented by a local NGO with the support of the government. It was designed in such a manner that San children have access to education in their native language for the first three years of their education (Hays 2009). It aimed to incorporate San indigenous knowledge systems into the governmental educational curricula (Hays 2009, 2000).

In this light, the characteristics of indigenous peoples that are set out in the global framework such as those proposed by Cabo are somewhat inefficient (Cobo 1985). One may take the feature that indigenous peoples pre-existed colonialism, conquest or invasion. As highlighted above, in many African countries Africans where already settled there before colonialism and with this criterion all Africans would be considered indigenous (Viljoen 2010, 76). Viljoen (2010, 78) has highlighted that in the African context the reconceptualization of the term indigenous would mean that the characteristics that identify indigenous peoples will shift slightly from those set out in the global indigenous movement. A critical feature is that indigenous peoples form non-dominant sectors of society and they are extremely marginalized. In post-colonial Africa, most countries are pluralistic in the sense that they are constituted by many ethnic groups including groups that self-identify as indigenous and those that do not, minority groups and dominant groups. The general sense is that due to the economic instability in many African countries the level of indigence is very high. Indigenous communities do not receive support from the government and are not recognized within the international framework of indigenous peoples. Viljoen however goes a step further and highlights that to distinguish indigenous populations in the African context would require more technical lenses i.e. the criteria would consider "the extent of their marginalization and vulnerability" (Viljoen 2010, 78). 
The argument is that instead of upholding the term 'indigenous peoples', in the fight for recognition of their individual and collective rights, a substitute term should be used: "Extremely vulnerable minorities" (Viljoen 2010, 79). This suggestion has been criticized by the African Union Commission, arguing that the narrative on minority rights is significantly different from that of indigenous populations. The minority rights narrative focuses on individual rights, negating the collective rights component which is core in the fight for the recognition of indigenous rights. Significantly, the African Union Commission advocates for indigenous rights protection independent of the minorities discourse. In 1999, Asbjørn Eide and Erika Irene Daes prepared a working paper for the UN Sub-Commission on the Promotion and Protection of Human Rights "on the relationship and distinction between the rights of persons belonging to minorities and those of indigenous peoples" (Eide \& Daes, 2000). The paper concluded that the two terms should be used distinctively though there may be overlapping characteristics, and that this is inevitable. Daes argued that a 'purposive' approach should be adopted focusing on what rights are being sought to be protected or rather what issues of the specific group need to be addressed as well as the legal consequences of such (Eide \& Daes, 2000, 10). As highlighted by the African Union Commission, it makes a significant difference where indigenous rights are recognized for what they are, collective in nature and accorded a space in the African human rights system as such (Report of the African Commission's Working Group of Experts on Indigenous Populations/Communities 2005, 96).

Be that as it may, the standards set out under international human rights law are intended to improve and promote recognition and protection of indigenous rights. Freeman $(2011,91)$ notes that the impasse with international human rights law is that it has a universalistic approach which unintentionally creates structural inequalities, and these conceal the causes of human rights violations. In as much as it is prudent to have a human rights regime that is structured and homogenous, it is also essential in the case of indigenous rights protection to tailor the concept into what works based on evidence and the lived realities of indigenous populations in post-colonial Africa. Failure to realize this will result in a futile task of trying to compel governments to conform to international standards, which might be a losing battle and indigenous peoples' rights continue to be violated. It is therefore imperative that the African indigenous rights movement rethinks and restructures its strategies in seeking the protection of indigenous rights. 
Moreover, there should also be an ambition to understand real politics and power struggles that have influenced the stagnation of the African indigenous rights movement so far. Gaventa presents a power analysis structure and highlights that power as a phenomenon can be utilized to "find ways to strengthen the capacity of ordinary citizens and to analyze and challenge the inequalities of power which affected their issues" (Gaventa 2006, 24). He argues that it is this understanding of power which enables citizens' voices to be heard at both local and global levels. The power intervals entail understanding power as a phenomenon alluded in different spaces and in different forms (Gaventa 2006, 25-26). Change can only be attained, therefore if there is an understanding of the power struggles that exist in the spaces, in this case, the dimension and dichotomy between states and the indigenous rights movement. The form of struggles that have contributed to the impasse that exists today in the recognition of indigenous peoples is politically motivated. Viljoen $(2010,77)$ notes that one of the primary reasons for the resistance camp is that the recognition and protection of indigenous rights is tied to the right to self-determination of indigenous populations. Common Article 1 to the Twin Covenants and UNDRIP provides for this right. The reluctance stems from the belief that recognition of indigenous rights as articulated under international law will result in the disintegration of the nation-state or territorial integrity in post-colonial Africa when this is not actually the case (Quane 2005, 660).

This reluctance and hostile opposition has been long standing and was exhibited during the negotiation period of the Declaration. In 2006, shortly after the UNDRIP reached the UN General Assembly (UNGA), from the Human Rights Council in Geneva, African states raised serious concerns regarding several provisions and managed to defer its adoption. Barume (2009, 171-172) notes the following:

As a group, African States and Governments (the African Group) made public their seven major concerns in a five-page document entitled "Draft Aide Memoire" dated 9 November 2006.5 First, the African Group underlined the need for a formal definition of the term "indigenous", which, it argued, would make it easier to identify the holders of the rights enshrined in the Declaration. Reference was also made to inter-ethnic tensions that could be exacerbated by recognizing special rights to sections of African populations. Secondly, the African Group objected to an indigenous peoples' right of self-determination under articles 3 and 4 of the Declaration, fearing political instability, secessions and threats to the territorial integrity of African states. Third, Article 5 of the Declaration, on the 
right of indigenous peoples to political social and cultural institutions, created fears among African states, which considered such a right to be in contradiction with several constitutions that promote unified states. Fourth, the right to belong to an indigenous community or nation in accordance with the traditions and customs of the nation or community was seen by the African Group as a green light for indigenous communities to change their nationalities freely, thus leading to political instability. Fifth, the African Group feared that the right of indigenous peoples to free, prior and informed consent would emerge as a veto mechanism to national legislation. Sixth, the African Group viewed indigenous peoples' rights to lands, territories and resources which they have traditionally owned, occupied, used or acquired as legally unworkable and in breach of states' rights over land and natural resources. Seventh, the African Group objected to the provisions of the Declaration on the right of indigenous peoples to recognition, observance and enforcement of agreements, treaties and other constructive arrangements historically concluded with states.

The African Commission on Human and People's Rights issued a legal opinion during the negotiation process, which opinion demonstrated that there were legal safeguards against any negative impact of the Declaration on the continent (Barume 2009, 178179). In the final, African states agreed on nine amendments to the original texts adopted by the Human Rights Council. The main issue of contention was territorial integrity and those who were in support of the Declaration offered and in exchange the African Group agreed to drop most of its suggested amendments on other issues, including to the provisions on lands, territories and resources (Barume 2009, 180). In particular, African states succeeded in incorporating a clause emphasizing territorial integrity of states, to avoid secession as a way to realize self-determination. With this in mind, the question then remains: how can the human rights regime promote the protection and recognition of indigenous rights in Africa?

\section{Indigenous Rights and Human Rights}

"Cultural diversity plays today a prominent role in the updating and developing of human rights. Past developments in the protection of rights have essentially forgotten the democratic management of cultural and identity-based diversity... The current context of regional progressive integration and social diversification within each state agrees on the need to address the adequacy of systems for 
the protection of rights from different strategies to the context of multiculturalism (Ruiz Vieytez 2014, 1).

Melting pot' theorists argue that modernization, development and economic growth will result in the fading of sub-state ethnic identities and consequently related conflicts (Venkatasawmy 2015, 30). Yet, in the last four decades, people have become more aware of their ethnic identities and human rights have been instrumental in protecting these interests. The complexity of the indigenous rights movement makes the contributions by different scholars significant in shedding light on achieving systems that are sensitive to cultural diversity and thus respecting and protecting the rights of indigenous populations. Ruiz Vieytez outlines that different strategies are particularly necessary to ensure that there is an inclusion of multiculturalism in the face of social diversification. His work refers to how cultural and identity-based diversity has been sidelined through the 'nationalization of rights' (Ruiz Vieytez 2014, 1). In essence, States have strived for a homogenous system that is driven by national interests but neglects the identities that make-up these interests. Diversity plays a crucial role not only in ensuring that the human rights of different collective identities are respected but also in the formulation and enactment of domestic standards and policies. The domestic approach, structure and standards on diversity shape how human rights recognize multiculturalism and as suggested by Ruiz Vieytez $(2014,2)$, there is need to 'adopt a strategy for pluralization' which is based on the different cultures and identities that make up a state including indigenous populations.

In this regard, Banard (1992) makes an interesting observation on the relationship between indigenous rights and human rights. He notes that the core components in the indigenous rights discourse are indigenous populations' right to land and their right to access natural resources. In his analysis, he indicates that these components are essentially human rights and as such there really is no need to make a distinction of rights but rather utilize the existent human rights structure to promote and protect indigenous rights. This presents an interesting issue which on face value seems to provide a solution to the quandary on the recognition and protection of indigenous rights. The idea of not having a 'special category' of indigenous rights and protecting indigenous rights as human rights shields the movement from the resistance that governments have continued to exhibit even post UNDRIP.

But the question on whether such an approach will diminish the claims of indigenous populations and thus lead to forced assimilation, 
alienation and its use by states to deny human rights ought to be addressed. The argument is that the human rights regime though complex in nature, is comprehensive such that it provides for tools such as ethno-cultural diversity which promote a variety of fundamental freedoms such as the right to equality. Ethno-cultural diversity entails a recognition of societal intersectionality with an aim to achieve equality. It reflects diversity and though it has been distinctively used in the minorities discourse, I argue that it is not limited to that discourse alone. It can be effectively used as a tool to achieve equality in the indigenous rights discourse and other contested dimensions of the human rights field (Pentassuglia 2017). If well executed, such a new approach to indigenous rights, would complement all efforts on indigenous rights protection and protection and would capture the gravity and need to recognize and promote both individual and collective rights of indigenous populations. It is not to replace the discourse on indigenous rights but will work as a propellance tool that brings the concerns of indigenous peoples to the agenda of governments. The basis of this avenue would be the right to equality which provides for non-discrimination, the need for governments to remove barriers which prevent certain groups of individuals from exercising their rights on an equal footing as others. This then shatters the argument that ethno-cultural diversity is a socio-political category applicable to minorities but not to indigenous peoples. The idea is not to make the indigenous rights discourse overshadowed by the minorities discourse but to ensure that the rights of indigenous peoples are protected independently with a grounding on the right to equality and the promotions of their human rights. This approach would allow for an avenue which comprehends all the components of the issues that the indigenous movement has for so long been fighting for and would be a step towards achieving the 'goal' which is recognition, promotion and protection of indigenous rights in Africa.

This approach to indigenous rights, within a wider human rights framework would fall in line with the role nowadays played by ethnocultural diversity in the general human rights discourse. Pentassuglia (2017) argues that ethno-cultural diversity is a growing category in human rights and therefore shapes human rights conceptualization at different levels and in different contexts. In this manner, it is important that the human rights discourse understands the collective interests of indigenous populations and how they relate to the wider political and national mechanisms (Kuper 2003). Taking this into consideration allows for the inclusion of these collective interests into the broader nation building perspective. International standards also play a crucial 
role and the human rights regime has set standards on the inclusion of diversity. This comprehension raises questions which are to be answered from legal, political and sociological perspectives. Can we use ethno-cultural protections to foster the recognition and protection of indigenous rights? What are the aims of human rights? What is apparent is that the discourse of human rights and ethno-cultural diversity is only pragmatic where it is sensitive to context (Pentassuglia 2017, 1-3). In that regard, the main concern in many contexts would be in view of the right to self-determination (Ughi 2012). States that are against recognizing indigenous rights do so on the premise that this will result in the destabilization of the nation and sovereignty (Quane 2005). As noted by Pentassuglia $(2017,5)$, UNDRIP provides for this right and it recognizes that internal self-determination is particularly significant. This therefore entails that the domestic system is formulated to recognize, respect and protect the rights and interests of different identities.

Ethno-cultural diversity has been translated as central in contemporary human rights jurisprudence and this can be seen in regional human rights courts (Pentassuglia 2017, 2). In the InterAmerican Court of Human Rights, the case of Awas Tingni is significant as the Court's decision protected indigenous ancestral land and natural resources thus reversing subjugation and discrimination of the Awas Tingni community 6 . Similarly, the recent judgment of the African Court on Human and Peoples Rights on the Ogiek case also provided that the Ogiek peoples, as the custodians of the Mau Forest Complex had the right to the land and were not to be evicted from their land ${ }^{7}$. The issue of equality and non-discrimination plays a crucial role as it is the basis on which the current human rights discourse is based on. These developments are particularly significant because they are a driving force towards inclusivity and the aim is for domestic systems to adopt such an outlook on the interests of different groups especially indigenous populations and rights protection. As noted by Pentassuglia (2017, 10-12), the relationship between human rights and ethnocultural diversity is complex and thus requires various implementation

6 Case of Mayagna (Sumo) Awas Tingni Community v Nicaragua, Merits, reparations and costs IACHR Series C No. 79 [2001] 31 August 2001, Inter-American Court of Human Rights. Available online at, http://www.corteidh.or.cr/docs/casos/ articulos/seriec_79_ing.pdf Last accessed on 14 May 2018.

7 African Commission on Human and Peoples' Rights $v$ Republic of Kenya, Application No. 006/2012 Judgment issued 26 May 2017, African Court on Human and Peoples Rights. Available online at, http://www.corteidh.or.cr/docs/casos/articulos/ seriec_79_ing.pdf Last accessed 14 May 2018. 
strategies that are shaped by the domestic political, cultural and social systems. Clearly, its sustenance is dependent on the existing machinery supporting human rights protection. It is not a straight forward process but rather a recurring attempt to reconciliate somewhat conflicting rights with the aim to include all people and ensure that the rights of different groups are recognized and protected.

It is apparent that the body of knowledge on this topic is somewhat diverse and ought to be contextualized. I position myself with the need for a rigorous approach aimed at sanctioning a structure that respects the human rights of all peoples and that recognizes and promotes indigenous rights protection whilst contextualizing indigenous rights and utilizing mechanisms already set out in the international human rights regime.

\section{Case Study: The Tshwa San Peoples in Zimbabwe}

\subsection{Zimbabwe's Approach to Indigeneity}

The defence of cultural diversity is an ethical imperative, inseparable from respect for human dignity. It implies a commitment to human rights and fundamental freedoms, in particular the rights of persons belonging to minorities and those of indigenous peoples. No one may invoke cultural diversity to infringe upon human rights guaranteed by international law, nor to limit their scope. (UNESCO 2001, Article 4)

The preamble of the Constitution of Zimbabwe (2013) provides that the people of Zimbabwe are united in their diversity with the common desire for freedom, justice and equality. It goes further to celebrate the various traditions and cultures in Zimbabwe. The right to culture is provided for in Section 16 emphasizing that the State, all institutions, government agencies and citizens have the obligation to "promote and preserve cultural values and practices which enhance the dignity, well-being and equality of Zimbabweans." In essence, this is a recognition of the validity of all cultures and traditions in Zimbabwe. Section 56 introduces the concept of equality and non-discrimination, recognizing that every person has the right not to be treated in a discriminatory manner on the basis of culture. Of greater importance is Section 56 (6) which makes it an obligation of the State to ensure that there is equality of all people by taking reasonable legislative and other measures in the case of people who have been disadvantaged by 
unfair discrimination. The protection of indigenous peoples falls under this specific section as indigenous peoples have suffered oppression in colonial Rhodesia and continue to suffer forced alienation and assimilation in post-colonial Zimbabwe. The government therefore has the obligation to provide equitable measures for indigenous peoples and as noted in section 56 (6) (b), such measures are necessary and do not tantamount to discrimination of other groups.

It is significantly interesting that the Constitution of Zimbabwe, which is the Supreme law of the land is cognizant of cultural diversity and the different cultural groups and identities in Zimbabwe. It allows every person to participate in the cultural life of their choice. In the same regard, the recognized official languages reflect the diversity of cultural identities in Zimbabwe. Section 6 recognizes Chewa, Chibarwe, English, Kalanga, Nambya, Ndau, Ndebele, Shangani, Shona, Sign language, Sotho, Tonga, Tswana, Venda and Xhosa as the official national languages. The general composition of the population is as follows:

\begin{tabular}{lr}
\hline Shona & $71 \%$ \\
Ndebele & $16 \%$ \\
Other African decent ethnic groups & $11 \%$ \\
Whites & $1 \%$ \\
Asians and people of mixed ancestry & $1 \%$ \\
\hline
\end{tabular}

Source: Internet Archive, 2011.

\subsection{San Peoples in Zimbabwe}

In Zimbabwe, two ethnic groups self-identify as indigenous peoples, the Doma peoples and the Tshwa San peoples. Over the years, it has been difficult to maintain a correct record of the total population of these groups due to relocation to other communities in search for better opportunities (Hitchcock \& Begbie-Clench 2016). Cultural Survival noted in a 2016 report that there are about 2,600 Tshwa San and 1,050 Doma peoples thus making up around 0.03\% of the country's total population (Cultural Survival 2016). These groups are not however recognized by the government as indigenous peoples but rather as ethnic minorities. It is important to note that Zimbabwe 
has signed UNDRIP but has not ratified ILO Convention 169. Despite signing UNDRIP there has not been any shift in terms of the protection of indigenous rights and implementation of standards set out in the Declaration. There is no domestic legislation dedicated to indigenous peoples, but the Constitution of Zimbabwe refers to 'indigenous Zimbabweans'. In that context, the definition of indigenous peoples is not given and a further reading into domestic legislation shows that the Indigenization and Economic Empowerment Act provides such a definition and it provides that an 'indigenous Zimbabwean' is: "any person who, before the 18th April 1980, was disadvantaged by unfair discrimination on the grounds of his or her race, and any descendant of such person" 8 .

This definition is premised on the historical injustices brought about by the colonization of Zimbabwe by Great Britain. Politically speaking, the term refers to black Zimbabweans. In light of this position, the general view of the government is that all black Zimbabweans are indigenous and as such do not make a distinction with regards to the San peoples. This situation was aptly captured by the UN Special Rapporteur (Daes 2001) as follows:

The legacy of colonialism is probably most acute in the area of expropriation of indigenous lands, territories and resources for national economic and development interests. In every sector of the globe, indigenous peoples are being impeded in every conceivable way from proceeding with their own forms of development, consistent with their own values, perspectives and interests. Much large-scale economic and industrial development has taken place without recognition of and respect for indigenous peoples' rights to lands, territories and resources. Economic development has been largely imposed from outside, with complete disregard for the right of indigenous peoples to participate in the control, implementation and benefits of development.

UNDRIP has been transposed in section 13 of the Constitution of Zimbabwe to the extent that it is therefore applicable to all Zimbabweans without distinction. This understanding challenges the recognition and protection of the San peoples who are marginalized and excluded in the legal, political and social structures. Such discrimination

8 Section 2(b), Act available online at, http://www.zimlii.org/zw/legislation/numact/2013/Amendment \%20No. \%2020\%20 of \%20The \% 20Constitution \% 20 of\%20 Zimbabwe/Constitution \%20of\%20Zimbabwe\%20-\%2020th\%20Amendment\%20 22\%20May\%202013.pdf Last accessed, 5 April 2018. 
is also reported in the educational frameworks as teachers and other pupils discriminate against Tshwa San children who are enrolled in government schools as they are considered as non-progressive. This undermines their culture and has resulted in many children dropping out of school and also takes away any hope of San peoples having the educational qualifications required for one to hold influential positions in the community or establish a career. The government has not made efforts to tailor educational facilities, which are friendly and compatible with the indigenous peoples' cultures. Cultural Survival $(2016,4)$ makes a note that programs such as the Village Schools Project, which is being conducted among the Nyae Nyae San in Namibia and Botswana, would be appropriate in the circumstances.

In recent years the San peoples have started to speak out about their situation seeking recognition from the government. They developed a community-based project-the Tsoro-o-tso San Development Trust which represents them in governmental platforms and also works with different organizations (Hitchcock, Begbie-Clench, Mberengwa \& Ndlovu 2017, 2). Organizations working on the ground are the Center for Community Development in Zimbabwe, and the Open Society Initiative for Southern Africa (OSISA), which works in the San community advocating for the promotion of their rights. The San community is greatly isolated and marginalized, and they live in abject poverty (Hitchcock, Begbie-Clench, Mberengwa \& Ndlovu 2017). Land is central to the identity of the Tshwa San with regards to hunting and gathering, natural resources and spiritual sites. Their access to land has been seriously affected by the fast track land reform program in Zimbabwe, which was conducted by the government in 2001. The land that they occupy is communal land that is owned by the government and the Tshwa San peoples have essentially not benefited from the land reform program (Hitchcock, \& Begbie-Clench 2016, 36). The Tshwa have been displaced from their land that is now part of the Hwange National Park and the Matopo Hills Recreational area. They have no access to these areas unless they pay the entrance fee. This is a contravention of their cultural rights. As provided in the Declaration, they have the right to access these areas as they are tied to their ancestral land especially the Matopo Hills where there are caves and stone writings of their ancestors (Hitchcock \& BegbieClench 2016, 54-55). Further, there has not been any benefit sharing strategy to ensure that the Tshwa San community benefits from such recreational developments as required in article 10 of the Declaration. This has affected their way of economic survival and they continue to live in poverty, as they are not skilled farmers and do not have the 
inputs to ensure successful harvests. The government has not made adequate efforts to improve the situation of Tshwa San as marginalized indigenous peoples (Hitchcock \& Begbie-Clench 2016, 36).

There are continuous efforts to assimilate Tshwa San peoples into dominant ethnic cultures particularly the neighboring Ndebele and the Kalanga groups. The Tshwao language though recognized in the Constitution is not documented and very few members of the San community can actually speak the language fluently. Currently less than twenty Tshwa San members are fluent speakers of the Tshwao language (Hitchcock, Begbie-Clench, Mberengwa, \& Ndlovu 2017, 5). The lack of development in the Tsholotsho area is an adverse force driving the San community to find alternative means of survival as they have no support from the government (Hitchcock \& Begbie-Clench, 2016). In 2016, at the Southern African Development Committee meeting, Zimbabwe's former President, Robert Mugabe stated that, "the San resist integration with neighboring communities, rebuff civilization and shun education, integration and development" (International Working Group on Indigenous Affairs 2016, 450). The government is not making efforts to ensure that there is development of the Tshwa community through preserving and promoting their culture (Pheage, 25 May 2015). As a result, there is an inevitable extinction of the San culture in Zimbabwe and there is urgent need to refocus and restrategize efforts on recognizing, promoting and protecting their human rights.

\subsection{Reversing the implementation gap: Ethno-cultural diversity as a tool for indigenous rights protection in Zimbabwe}

As illustrated above, there is a huge implementation gap with regards to the protection of indigenous rights in Zimbabwe as is the case in many African countries. There has been failure by the government of Zimbabwe to comply with UNDRIP which it has signed. Musamba (2015, 34-35) has argued that in the African governance system collectivism is central. There is a focus on commonalities to annihilate 'divisive issues', thus it is an embedded factor resulting in the outright disregard of ethno-cultural identities. This focus creates a culture of oppression and neglect of cultural diversity as an important element in the human rights discourse.

To understand the role that ethno-cultural diversity can play in protecting indigenous rights it is important to look at the underlying functions of human rights. Human rights are universalistic and pluralistic in nature thus they are deemed to be applicable to all 
persons without distinction and in all contexts (Freeman 2011). As such human rights have a homogenous outlook and Walker expediently describes human rights as being 'open minded' (Pentassuglia 2017, 10). What does this mean? The international human rights regime is designed in a scope that is inclusive of all individual and collective rights. In those parameters, what distinguishes the levels of protection is the context. Ethno-cultural diversity aids in protecting human rights through recognizing and incorporating individual and collective interests as well as considering the political and cultural context. It is instrumental in creating a system through policies that are sensitive to the cultural identities that make up societies.

However, as has been noted in this paper, arguments have been raised to undermine the validity of ethno-cultural diversity as a tool for human rights implementation and this is worth analyzing. The modernization theory argues that systemic recognition of ethnic identities deters development and thus has a direct implication on human rights protection (Venkatasawmy 2015, 31). The rationale of the modernization theory is that the availability of resources and development including economic growth exposes the discrimination and inequalities of a system where there is no equal distribution of resources. Subsequently this creates tension between sub-state ethnopolitical groups resulting in conflict. This theory holds some truth however fails to realize that it is not ethno-cultural diversity which results in the disintegration of society but rather a system of faulted, corrupt and discriminatory governance. Weighing this view against the broader perspective of human rights, I would argue that the current body of scholarship acknowledges the function that ethno-cultural diversity has in promoting human rights protection. As argued by Chapman, "the suppression of diversity facilitates rather than contains conflict". (Pentassuglia 2017, 23).

The governance system in Zimbabwe is bi-structured between black Zimbabweans and non-black Zimbabweans. Since gaining independence, the Zimbabwean government has directed its efforts on empowering the full representation and participation of black Zimbabweans. This emphasis was on ensuring that black people have the right to vote, access to agricultural land and equal participation in the economic and political life (Coltart 2018). With this framework in place, the diversity among black Zimbabweans has been to a greater extent disregarded. As illustrated in table 1 above, the Shona and Ndebele are the prominent groups in Zimbabwe, with the Shona being the majority. It is therefore these dominant groups that are involved in the political and economic decision making; they thus formulate policy 
which sidelines the indigenous population. As such the failure of the government to adopt a system that is cognitive of intra-state ethnocultural diversity has culminated in human rights violations particularly of the indigenous rights of the San people. There is also a clear violation of the fundamental right to equality and non-discrimination. Article 5 of the Declaration provides that indigenous peoples have the right to maintain their distinct nature. This means that the government of Zimbabwe should not treat the Tshwa San peoples the same as the Ndebele or Shona groups who do not fall within the ambit of indigeneity as provided by the African Commission (2005). The position by the former President of Zimbabwe Robert Mugabe that the San peoples are 'backward and shun development' contradicts international human rights standards (International Working Group on Indigenous Affairs 2016). It is an attempt to assimilate them into the dominant Shona and Ndebele cultures which violates article 8 and in turn article 12 which gives indigenous peoples the right to practice their own religious, spiritual traditions and customs.

Another important issue is the displacement and forced resettlement of the Tshwa San peoples by the government. Article 10 provides that free, prior and informed consent should be obtained by the government before resettling indigenous peoples. The Tshwa San peoples were not consulted in the development of the recreational facilities in their ancestral lands hence the government did not fulfill the safeguards. Article 11 provides that indigenous peoples ought to have control of historical sites, which form part of their identity as indigenous peoples. The fact that the Matopos Hill was made into a national site when it is a spiritual and historical site of the Tshwa San clearly violates their rights. Precedence was set in the case of Saramaka People $v$ Suriname ${ }^{9}$, the Inter-American Court of Human Rights provided that the government has to obtain free, prior and informed consent from the peoples. Where developments are to be conducted on indigenous peoples' land then indigenous peoples should have a guaranteed benefit from these developments and this should be in terms of their cultural values and customs. This was not done in the case of the Tshwa San peoples; they have not been compensated for their displacement and this is a direct violation of their rights.

${ }^{9}$ Case of Saramaka Peoples v Suriname. Interpretation of judgment on Preliminary Objections, Merits, Reparations and Costs. IACHR Series C No. 185, IHRL 3058 (IACHR 2008), 12 August 2008, Inter-American Court of Human Rights. Available online at, http://www.corteidh.or.cr/docs/casos/articulos/seriec_172_ing.pdf Last accessed 15 May 2018. 
The standards set out in UNDRIP (which Zimbabwe has ratified) are clear and ensure that indigenous peoples rights are recognized and protected. Despite the complexities of indigeneity in Zimbabwe, the direct violation of human rights should be unacceptable.

The situation in Zimbabwe represents the typical case of indigenous rights violation in many African countries. To close the implementation gap, there ought to be a balance between human rights protection and contextualization of the human rights of the Tshwa San peoples. Contextualization of human rights is the impending move that those seeking to protect the indigenous rights of the Tshwa San peoples should focus on. Where human rights are protected, and ethnocultural diversity respected then indigenous rights are protected and promoted. An emphasis on the need to recognize indigenous rights is equally crucial and should not be perceived by the government of Zimbabwe as giving special rights but equitable rights. In light of the government's competing legislative and policy priorities, I propose that Zimbabwean advocates on these issues and those who support them should instead explore the ethno-cultural diversity narrative as an alternative avenue towards the protection of indigenous rights. This approach entails diverting focus from the politics of recognition and emphasizing on indigenous rights as human rights and facilitating the protection of these rights through ethno-cultural protections. It is not a straight forward process but rather a recurring attempt through policy formulation (Pentassuglia 2017).

\section{Conclusions}

Although most African countries have taken tentative steps to recognize the existence of various ethnic minorities, a chasm still exists between such groups' realities and the articulation of rights enshrined in the national Constitutions, the African Charter on Human and Peoples Rights and international human rights instruments meant to protect them. Indigenous peoples are the worst affected by the nonrecognition of their status as an indigenous people and despite the coming into effective of UNDRIP no concrete efforts and measures have been put in place to facilitate the promotion of indigenous rights.

While most Constitutions clearly recognize ethnic diversity, the governments are yet to formulate and implement concrete legislative policy measures to realize ethnic parity and diversity. Given the volatile political contexts in many African countries and the fact that indigenous rights are not at the top of their agendas, an emphasis on the need for 
the government to recognize indigeneity might not be a short-term solution for indigenous rights protection. Rather, there has to be efforts that are tailored directly to facilitate robust human rights protections. Therefore, indigenous rights advocates should rely on community based and government-initiated approaches to addressing the chasm. Although, an overall emphasis on recognition of indigeneity should not be abandoned as there is need to continuously dissect the complexities associated with the concept, the adoption of such an ethno-cultural diversity narrative would provide an alternative 'social' avenue towards the protection of indigenous rights while being sensitive to the unstable political climate. This approach entails diverting focus from the politics of recognition to an emphasis on indigenous rights as human rights and facilitating the protection of these rights through ethno-cultural protections and the development agenda. In this regard, development efforts will be based on the recognition of collective rights to land, ancestral territories and natural resources. Although the role of ethnocultural diversity in human rights discourse is contested due to a lack of clarity of both international standards and traditional analysis, an organic, inclusive, and evolutionary broad-based approach facilitates sustainable and significant changes in the realities of indigenous communities. In practical terms this means that indigenous rights as human rights are allocated a conducive environment under which States do not interfere with the rights of indigenous communities at all costs. Practically, this could be implemented through donor funded community-driven initiatives that would ultimately feed into policy making at local and national levels. It will ensure sustainable government policies and a sense of ownership among indigenous peoples borne out of the living reality of oppression, forced alienation, marginalization and assimilation.

\section{Bibliography}

African Commission on Human and Peoples Rights. 2000. "51: Resolution on the Rights of Indigenous Peoples' Communities in Africa". African Union on Human and Peoples Rights. October. Accessed March 1, 2018. http:// www.achpr.org/sessions/28th/resolutions/51.

African Commission's Working Group Of Experts on Indigenous Populations/ Communties. 2005. Report of the African Commission's Working Group of Experts on Indigenous Populations/Communities. African Commission on Human and Peoples Rights, Banjul, The Gambia: African Commission on Human and Peoples Rights, 119. 
Barnard, Alan. 1992. Hunters and herders of Southern Africa: A comparative ethnography of the Khoisan peoples, Cambridge: Cambridge University Press.

Barume, Albert K. 2009. "Responding to the concerns of the African States". Making the Declaration Work: The United Nations Declaration on the Rights of Indigenous Peoples. 170-183.

Battiste, Marie. 2002. "Decolonising University Research: Ethical Guidelines for Research Involving indigenous Populations". In Justice Pending: Indigenous Peoples and Other Good Causes, edited by Gudmundur Alfredsson and Maria Stavropoulou, 33-44. The Hague: Kluwer Law International.

Bojosi, Kealeboga, N. 2010. "The African commission working group of experts on the rights of indigenous communities/populations: some reflection on its work so far". In Perspectives on the rights of minorities and indigenous peoples in Africa, edited by Solomon Dersso, 95-140. Cape Town: Pretoria University Law Press.

Cobo, Martinez, R, Jose. 1985. Study on the Problem of Discrimination Against Indigenous Populations Final Report. United Nations, Special Rapporteur of the Sub-Commission on Prevention of Discrimination and Protection of Minorities, United Nations.

Coltart, David. 2018. "After Mugabe: Mnangangwa's choice", Policy: A Journal of Public Policy and Ideas, 34(1): 51-54.

Cultural Survival. 2016. Observations on the State of Indigenous Human Rights in Zimbabwe Prepared for United Nations Human Rights Council: 2nd cycle of Universal Periodic Review of Zimbabwe 26th session of the Human Rights Council. Cambridge, MA: Cultural Survival, 1-8.

Daes, Erica. 2001. "Indigenous peoples and their relationship to land: Final working paper prepared by the Special Rapporteur", UNHCR.

Dersso, A, Solomon. 2010. "The Socio-historical and Political Processes leading to the Emergence and development of norms on minorities". In Perspectives on the rights of minorities and indigenous peoples in Africa, edited by A, Solomon Dersso, 43-72. Cape Town: Pretoria University Law Press.

Eide, Asbjorn, and Irene, Erika Daes. 19 July 2000. Prevention of discrimination against and the protection of minorities: Working paper on the relationship and distinction between the rights of persons belonging to minorities and those of indigenous peoples. Commision on Human Rights. Sub-Commission on the Promotion and Protection of Human Rights, United Nations, Economic and Social Council, United Nations, Economic and Social council, 11.

European powers. 1648. "The Peace of Westphalia", Osnabrück and Münster, Germany.

Freeman, Michael. 2011. Human Rights. 2. Cambridge: Polity Press.

Gaventa, John. 2006. "Finding the Spaces for Change: A Power Analysis". Institute of Development Studies Bulletin, 37(6): 23-33.

Hays, Jennifer. 2009. "Learning Indigenous Knowledge Systems" 194-207.

Hays, Jennifer, and Megan Biesele. 2011. "Indigenous Rights in Southern Africa: International mechanisms and local contexts", The International Journal of Human Rights, 15(1): 1-10. 
Hitchcock, Robert K, and Ben, Murwira, Ashton Begbie-Clench. 2016. The san in Zimbabwe. Livelihoods, Land and Human Rights. IWGIA Report 22, Copenhagen: IWGIA-OSISA-University of Zinbabwe, 69.

Hitchcock, Robert, Ben Begbie-Clench, Ignatious Mberengwa, and Davy Ndlovu. 2017. "Zimbabwe". Edited by Wiben, Marianne Jensen. Indigenous World (International Work Group for Indigenous Affairs (IWGIA)) 534-539.

Hodgson, Louise, Dorothy. 2009. "Becoming Indigenous in Africa", African Studies Review, 1-32.

International Labour Organisation. 2009. A Guide to ILO Convention No. 169. International Labour Standards Department, Indigenous and Tribal Peopls' Rights in Practice, ILO, 201.

International Working Group on Indigenous Affairs. 2016. "Report on Zimbabwe-Indigenous World".

Internet Archive. 2011. The literature and culture of Zimbabwe. Accessed May 16, 2018. https://web.archive.org/web/20070712141810/http://www. scholars.nus.edu.sg/post/zimbabwe/zpeople.html.

Kenrick, Justin, and Jerome Lewis. 2004. "Discussion: On the Return of the Native", Current Anthropology 45(2): 263.

Kipuri, Naomi. 2005. "The Working Group of the African Commission on Human and Peoples' Rights on the situation of indigenous Populations and Communities in Africa", IFAD Governing Council Metting. Rome: United Nations.

Kuper, Adam. 2003. "The Return of the Native", Current Anthropology, 44(3): 389-402.

Malloy, H, Tove. 2006. "Towards a New Paradigm of Minority Law-Making: A Rejoinder to Palermo and Woelk's Law of Diversity", European Yearbook of Minority Issues (Koninklike Brill NV) 4: 5-28.

Musamba, C. 2015. "Cultural Diversity and Democratic Global Cooperation: A perspective from Africa", Global Dialogues.

Nabudere, Wadada, Dani. 2005. "Human Rights and Cultural Diversity in Africa", Conference on The Fusion of Legal Systems and Concepts in Africa. Entebbe: Association of Law Reform Agencies of eastern and Southern Africa (ALRAESA). 8.

Parliament of Zimbabwe. 2017. "Constitution of Zimbabwe (Ammendment No. 20)", Constitute Project. November 23. Accessed March 12, 2018. https://www.constituteproject.org/constitution/Zimbabwe_2013.pdf.

Pelican, Michaela. 2009. "Complexities of indigeneity and autochtony: An African Example", American Ethnologist, 36(1): 52-65.

Pentassuglia, Gaetano. 2017. "Introduction: The Unpacking of Ethno-Cultural Diversity". In Ethno-Cultural Diversity and Human Rights Challenges and Critiques, edited by Gaetano Pentassuglia, 1-24. Leiden: Brill | Nijhoff.

Pheage, Tefo. 25 May 2015. "Mugabe, Basarwe clash over civilization diatribe". Available online at, http://www.weekendpost.co.bw/wp-newsdetails. php?nid=1054, Weekend Post, 1.

Quane, Helen. 2005. "The Rights of Indigenous Peoples and the Development Process", Human Rights Quarterly, 27: 652-682. 
Raz, Joseph. 1988. The Morality of Freedom. Oxford: Oxford University Press. Reference Re Secession of Quebec. 1998. [1998] 2 S.C.R.217 (Supreme Court of Canada, Supreme Court of Canada Judgments August 20).

Robins, Steven. 2003. "A comment to Adam Kuper's «The Retirn of the Native»", Current Antropology 44(3): 398-399.

Ruiz Vieytez, Eduardo. 2014. "Cultural Diversities and Human Rights: History, Minorities, Pluralization", The Age of Human Rights Journal 3: 1-31.

Suzman, James. 2003. "A comment to Adam Kuper's «The Return of the Native»", Current Anthropology 44(3): 399-400.

Sylvain, Renee. 2017. "Indigenous Peoples in Africa". Oxford Research Encyclopedia of African History (Oxford University Press USA) 31.

Szpak, Agnieszka. 2017. "Human Security of the Indigenous Peoples in the Arctic. The Sami Case", Interdisciplinary Political and Cultural Journal 20(1): 75-96.

The African Commission on Human and Peoples' Rights at its 28th ordinary session. 2005. Report of the African Commission's Working Group of Experts on Indigenous Populations/Communities. Working Group on Indigenous Populations/Communities, ACHPR , ACHPR, 119.

Ughi, Cristina. 2012. "The «Right to Development» of Indigenous Peoples: A Critical Approach Through a Comparative Study of Cases Brought Before the Inter-American Court of Human Rights and the African Commission on Human and Peoples' Rights". The BSIS Journal of International Studies (Brussels School of International Studies at the University of Kent) 9: 1-27.

UNESCO General Conference. 2005. UNESCO Convention on the Protection and Promotion of the Diversity of Cultural Expressions. Paris, October 3-21.

UNESCO. 2001. Universal Declaration on Cutural Diversity. Paris: UNESCO.

United Nations General Assembly. 1948. Universal Declaration of Human Rights. Paris: www.un.org.

United to End Genocide. n.d. The Rwandan Genocide. Accessed May 10, 2018. http://endgenocide.org/learn/past-genocides/the-rwandan-genocide/.

Venkatasawmy, Rama. 2015. "Ethnic Conflict in Africa: A Short Critical Discussion", Transcience 6 (2): 26-37.

Viljoen, Franz. 2010. "Reflection on the Legal Protection of Indigenous Peoples' Rights in Africa". In Perspectives on the rights of minorities and indigenous peoples in Africa, edited by Solomon Dersso, 75-93. Cape Town: Pretoria University Law Press (PULP).

Webb, Jill. 2012. "Indigeous Peoples and the right to self-determination", Journal of Indigenous Policy 75(13): 75-102.

World Conference on Human Rights. 1993. "Vienna Declaration and Programme of Action". Vienna.

Yacoub, Joseph. 2010. "Cultural diversity and international law. In the field of human rights and identities", Revue internationale: International Webjournal (Sens Public) 1-12. 


\section{Copyright}

Deusto Journal of Human Rights / Revista Deusto de Derechos Humanos is an Open Access journal; which means that it is free for full and immediate access, reading, search, download, distribution, and reuse in any medium only for non-commercial purposes and in accordance with any applicable copyright legislation, without prior permission from the copyright holder (University of Deusto) or the author; provided the original work and publication source are properly cited (Issue number, year, pages and DOI if applicable) and any changes to the original are clearly indicated. Any other use of its content in any medium or format, now known or developed in the future, requires prior written permission of the copyright holder.

\section{Derechos de autoría}

Deusto Journal of Human Rights / Revista Deusto de Derechos Humanos es una revista de Acceso Abierto; lo que significa que es de libre acceso en su integridad inmediatamente después de la publicación de cada número. Se permite su lectura, la búsqueda, descarga, distribución y reutilización en cualquier tipo de soporte sólo para fines no comerciales y según lo previsto por la ley; sin la previa autorización de la Editorial (Universidad de Deusto) o la persona autora, siempre que la obra original sea debidamente citada (número, año, páginas y DOI si procede) y cualquier cambio en el original esté claramente indicado. Cualquier otro uso de su contenido en cualquier medio o formato, ahora conocido o desarrollado en el futuro, requiere el permiso previo por escrito de la persona titular de los derechos de autoría. 